\title{
THE AUCKLAND ISLANDS
}

\begin{abstract}
HE Auckland Islands are a small group about 200 miles south of New Zealand. They were discovered by Captain Bristow in 1806 and visited by American, French and British expeditions in 1840; their flora was studied by Sir Joseph Hooker; and in the days of sailing ships they were the cause of many wrecks, lying as they did on the route between Australia and Cape Horn. After the opening of the Panama Canal, they were left almost deserted-except for a period during the Second World War--until they were visited by an expedition from the Australian Museum during December-January, 1962-63. A preliminary account of this expedition has been published in Australian Natural History (14, No. 9; March, 1964).
\end{abstract}

The main Auckland Island is about 23 miles long, and 15 miles across at its widest part, bordered by precipitous cliffs on the western side while providing fine inlets and harbours on the east. Unlike all other windswept subantarctic islands, its coastal areas are covered with a thick growth of gnarled, stag-headed trees, of southern rata (Metrosideros umbellata), which rise to a height of $40 \mathrm{ft}$. Below these, specimens of the Macquarie Island cabbage (Stilbocarpa polaris), with strong antiscorbutic properties, are conspicuous, although they have been much reduced through the introduction of sheep, goats, cattle and rabbits.

Above the rate is a dense growth of scrubland vegetation (chiefly Dracophyllum and Suttonia) difficult to penetrate, although it is interspersed with lines of tussock grass (Danthonia and prostrate Coprosma). Both winged and wingless forms of a number of Diptera and Lepidoptera were taken, along with semi-apterous ichneumons, use being made of aerial nets in the ship's rigging. A new wingless cricket (Raphidophoridae) was found to be abundant at night.

Along the shores a supra-littoral zone, marked by white lichen, was found to change abruptly into a mid-tidal zone of bare rock, except for scattered barnacles and limpets. In turn, this zone changed into a lower-tidal one of encrusting coralline algae and the giant kelp (Durvillea antarctica), to be followed by an extensive zone of red and brown algae in the sub-littoral. In the rock pools, among the cryptic fauna of small gastropods, fish and worms, the expedition discovered large numbers of the small crab Halicarcinus planatus, the only intertidal crab on any subantarctic island. A large red spider crab, Jacquinotia, dominated the shallow water; two species of nototheneid fish were taken, along with the large crab, Leptomithrax australis, and the edible species, Cancer novaezealandiae.

Along the beaches, large numbers of Hooker's sea lion (Neophoca hookeri) were observed, the sandy beach on Enderby Island being crowded with these animals. Yellow-eyed penguins (Megadyptes antipodes) and crested penguins (Eudyptes) were plentiful, and among the other birds observed were Auckland Island shags (Phalacrocorax campbelli colensoi), red-billed gulls (Larus novaehollandiae), Antarctic terns (Sterna vittata), giant petrels (Marronectes giganteus), the sooty albatross (Phoebetria palpebrata), the southern skua (Stercorarius lonnbergi), prions (Pachytila desolata), diving petrels (Pelecanoides urinatrix), sooty shearwaters (Puffinus griseus), and white-headed petrels (Petrodroma lessoni). Of special ornithological interest were the large numbers of the Auckland Island flightless duck (Anas aucklandica) on Ocean and Ewing Islands.

But the expedition's most striking experience was a visit to a breeding colony of the southern race of the royal albatross (Diomedea epomophora), which is held to be the largest of all albatrosses, with a wing span of $11.5 \mathrm{ft}$. and a weight of $25 \mathrm{lb}$. This bird is known to nest only on Auckland and Campbell Islands, Taiaroa Head on the South Island, New Zealand, and on the Chatham Islands east of New Zealand.

\section{RESEARCH INTO RESEARCH}

$\mathrm{D}$ URING January-March a seminar was held in Stockholm to stimulate studies on research in social sciences. This seminar was arranged by the Academy of Engineering Sciences and supported by the Social Science and Technical Research Councils. Dr. Stevan Dedijer from the Sociological Institute of the University of Lund led the work. About half the thirty delegates were young social sciontists from the universities. The others came from the Ministries and Research Councils, and from certain large industrial firms and research establishments.

The seminar met in Stockholm for two days every other week, making a total of 10 days. During the intervals, each delegate worked on his individual problem. The programme consisted of some twenty lectures, with discussions. The rest of the time was devoted to discussing the delegates' projects and progress reports.

Visitors from overseas who addressed the seminar included: Dr. Charles Kidd, head of the office for International Research at the U.S. National Institutes of Health, who spoke on "Research, Universities and the Government in the United States"; Dr. Stephen Toulmin from the Nuffield Foundation in London, who gave a stimulating lecture on "Science as the Focus of Academic Study"; Chris Freeman from the National Institute of Economic and Social Research in England, who reported his penetrating investigations into the importance of innovations in the plastics industries of different countries; and Jean Jacques Salomon from the Secretariat of the Organization for Economic Co-operation and Development, Paris, who spoke on "Science and Foreign Affairs in Europe". Almost all the leading Swedish research administrators gave lectures to the seminar. Each aired his own views on activities in different areas of research and on the selective approach necessary in a country of Sweden's size.

Subjects which the delegates considered, and which will be included in the collected essays when they are published, are: methodological problems in connexion with research statistics; the Government budget process in the fields of university research and education; an investment calculus on research and development projects in Swedish industry; civilian utilization of results emanating from defence research and development in Sweden; the ageing of research workers; the development of the theory of planning of science.

The seminar was a bold experiment, but one which, in retrospect, appears to have succeeded in its essential aims. The primary object was to pin down linguistic usage in connexion with research, so as to be able to attack clearly defined problems within various disciplines of the social seience. A number of the investigations initiated by the seminar may clearly be of immediate relevance to Swedish research policy. The essential gain, however, is that young research workers have had 